\title{
Performa Produksi dan Kualitas Telur Ayam Petelur pada Sistem Litter dan Cage dengan Suhu Kandang Berbeda
}

\author{
Productive Performance and Egg Quality of Layer in Litter and Cage System with Different \\ Temperatures
}

\author{
T. Setiawati ${ }^{1}$, R. Afnan ${ }^{2}$, N. Ulupi ${ }^{2}$ \\ ${ }^{1}$ Fakultas Peternakan, InstitutPertanian Bogor \\ ${ }^{2}$ Departemen Ilmu Produksidan Teknologi Peternakan, Fakultas Peternakan, Institut Pertanian Bogor, Jl. \\ Agatis, Kampus IPB Dramaga, Bogor 16680, Indonesia
}

\begin{abstract}
ASBTRACT
Housing temperature and housing system may influence productive performance and egg qualities. This research aimed to investigate the influence of different housing temperatures and housing system on productive performance and egg qualities. A total of 72 Lohmann hens were reared in litter and cage system with different housing temperatures of $18{ }^{\circ} \mathrm{C}$ and $30{ }^{\circ} \mathrm{C}$. Each treatment consisted of 18 hens. Traits measured were productive performance (feed intake, hen day production, egg weight, egg mass, and feed conversion), egg internal and external qualities (egg shape index, Haugh Unit, air sack, albumin height, egg shell cleanless, egg shell thickness, and egg shell weight). This experiment was run twice according to housing system for each housing temperatures and was completely randomized design. Data was subjected to t-test and descriptive analyses. Productive production and egg quality in both housing systems did not differ. However, the egg weight was significantly heavier in cage system compared to litter system in neutral housing temperature.
\end{abstract}

Keywords: egg quality, housing system, housing temperature, productive performance

\section{PENDAHULUAN}

Ayam petelur merupakan salah satu ternak unggas yang cukup potensial di Indonesia. Ayam petelur dibudidayakan khusus untuk menghasilkan telur secara komersial. Saat ini terdapat 2 kelompok ayam petelur yaitu tipe ayam medium dan tipe ringan. Tipe medium umumnya bertelur dengan kerabang coklat sedangkan tipe ringan bertelur dengan kerabang putih (North dan Bell 1990).

Telur konsumsi dihasilkan oleh ayam ras petelur yang merupakan salah satu jenis unggas yang diternakkan di Indonesia. Populasi ayam ras petelur semakin meningkat dari tahun ke tahun dikarenakan semakin meningkatnya pemintaan masyarakat akan telur konsumsi. Menurut Direktorat Jenderal Peternakan, dalam kurun waktu 20002012 populasi ayam ras di Indonesia mengalami rata-rata peningkatan sebesar $0,61 \%$. Namun peningkatan populasi ini belum diiringi dengan peningkatan produktivitas ayam petelur. Oleh karena itu perlu dilakukan usaha untuk meningkatkan produktivitas ayam petelur, salah satunya melalui perbaikan sistem pemeliharaan.

Kandang merupakan tempat ternak melakukan aktivitas produksi, sehingga kenyamanan dan bentuk kandang perlu diperhatikan supaya ternak merasa nyaman dan tidak mengganggu proses produksi. Kandang ayam dapat berupa litter dan cage. Kenyamanan bergantung pada suhu kandang. Suhu kandang yang terlalu tinggi akan menyebabkan ayam petelur menjadi kurang nyaman dan dikhawatirkan akan menurunkan produktivitasnya dan juga menurunkan kualitas telur yang dihasilkan.

Ayam ras petelur yang dipelihara dengan sistem cage memiliki beberapa keuntungan secara ekonomi yaitu hemat tempat per unit area, praktis, mudah dipantau, dan berisiko kecil terhadap predator. Kelemahannya yaitu terbatasnya ruang gerak yang mengarah pada kesejahteraan hewan dan resiko penyakit akibat debu serta lalat dari kandang. Ayam ras petelur yang dipelihara pada sistem litter jarang dilakukan karena akan sulit dalam mengontrol konsumsi pakan per individu dan pengambilan telur, tetapi kelebihan dari sistem litter ini yaitu ayam yang dapat leluasa dalam kandang.

Sistem pemeliharaan dapat berupa suhu kandang dan jenis kandang yang digunakan selama pemeliharaan. Penggunaan suhu dan jenis kandang yang berbeda dapat mempengaruhi kualitas telur, baik kualitas interior maupun eksterior. Oleh karena itu penelitian ini akan mengamati dan mempelajari penggunaan suhu dan sistem kandang yang efektif untuk memelihara ayam petelur supaya produktivitas dapat maksimal. Penelitian ini bertujuan untuk mempelajari suhu dan sistem kandang yang sesuai untuk performa produksi dan kualitas telur ayam petelur.

\section{MATERI DAN METODE}

Waktu dan Tempat Penelitian

Penelitian dilakukan selama 6 minggu yaitu sejak 27 Agustus - 7 Oktober 2013, bertempat 
di kandang Laboratorium Lapang Unit B bagian unggas. Analisis kualitas telur dilakukan di Laboratorium Unggas Departemen Ilmu Produksi dan Teknologi Peternakan, Fakultas Peternakan IPB.

\section{Bahan}

Bahan-bahan yang digunakan dalam penelitian meliputi ayam petelur strain Lohmann sebanyak 72 ekor, telur ayam, sekam, pakan, air, dan vita stress. Pakan yang digunakan merupakan pakan komplit komersial untuk ayam petelur dewasa umur 19 minggu. Bahan-bahan dalam pakan yaitu jagung kuning, bungkil kacang kedelai, bungkil kacang tanah, tepung ikan, tepung daging, dedak padi, pollard, vitamin, trace mineral, dan antioksidan. Kandungan nutrisi dalam pakan disajikan pada Tabel 1.

Tabel 1 Kandungan nutrisi pakan

\begin{tabular}{llc}
\hline \multicolumn{1}{c}{ Nutrisi pakan } & \multicolumn{2}{c}{ Kandungan (\%) } \\
\hline Kadar air & Maks. & 13 \\
Protein kasar & Min. & 17 \\
Serat kasar & Maks. & 6 \\
Lemak & Min. & 3 \\
Abu & Maks. & 14 \\
Fosfor & & $0,6-1,0$ \\
Kalsium & & $3,0-4,2$ \\
\hline
\end{tabular}

Sumber: PT Gold Coin Indonesia

\section{Alat}

Alat-alat yang digunakan dalam penelitian ini adalah kandang cage, AC, heater, pembatas kandang, kardus, bambu, tempat pakan, tempat minum, jaring pembatas, lampu, egg tray, timbangan, termometer, jangka sorong, tripod, mikrometer skrup, dan label.

\section{Prosedur}

\section{Persiapan Kandang}

Kandang yang digunakan untuk pemeliharaan dibersihkan dari debu dan kotoran lalu didisinfeksi dengan air kapur hingga merata di seluruh lantai kandang. Setelah disinfeksi, pembatas atau sekat kandang dipasang di dalam kandang dan kandang cage diletakkan di dalam kandang.

Pembatas kandang dan kandang cage sebelumnya sudah dibersihkanterlebih dahulu. Kandang litter diberi alas sekam supaya dapat menyerap feses dan ekskreta. Kandang cage diberi alas karung dan sekam di bagian bawah kandang.

\section{Pemeliharaan Ayam}

Sebanyak 72 ekor ayam dipelihara pada 4 unit kandang, kandang litter sebanyak 2 unit dan 2 unit kandang lainnya cage. Satu kandang litter dan cage diatur pada suhu $18{ }^{\circ} \mathrm{C}$ menggunakan $\mathrm{AC}$ dan lainnya diatur pada suhu $30{ }^{\circ} \mathrm{C}$ menggunakan heater. Pakan ayam diberikan 3 kali sehari yaitu pagi, siang dan sore dengan jumlah $120 \mathrm{~g} \mathrm{ekor}^{-1}$ hari $^{-1}$. Air minum diberikan ad libitum.

Telur yang dihasilkan dikumpulkan setiap hari dan diberi kode. Penimbangan telur dilakukan setiap hari untuk menghindari penurunan kualitas telur berdasarkan bobot akibat penyimpanan. Suhu dicatat setiap pukul 9.00 pagi, 12.00 siang, dan 15.00 sore. Penimbangan sisa pakan pada kandang cage dilakukan setiap 1 minggu sekali, sedangkan pada kandang litter tidak dilakukan penimbangan sisa pakan karena pakan yang diberikan seluruhnya habis. Analisis Kualitas Telur

Analisis kualitas telur dilakukan di Laboratorium Unggas Fakultas Peternakan IPB. Bobot telur ditimbang menggunakan timbangan digital lalu diukur panjang dan lebar menggunakan jangka sorong. Telur diteropong (candling) untuk mengetahui kedalaman kantung udara. Selanjutnya telur dipecahkan di atas meja kaca datar dan tinggi putih telur diukur menggunakan tripod.

Bobot kerabang yang sudah bersih dari sisa-sisa putih telur ditimbang, kerabang bagian tengah, tumpul, dan runcing diambil (tanpa selaput) untuk diukur tebalnya menggunakan mikrometer skrup. Kualitas eksterior telur meliputi abnormalitas, bentuk, keutuhan, dan kebersihan kerabangtelur.Abnormalitas telur ditentukan daribentuk telur yang tidak semestinya. Bentuk telur dikelompokkan menjadi lonjong, agak bulat, dan oval. Keutuhan kerabang diamati dari retak atau tidaknya kerabang dan kebersihan telur diukur dari banyaknya kotoran yang menempel pada kerabang.

Konsumsi pakan dihitung berdasarkan selisih pakan yang diberikan dengan pakan yang tersisa. Hen day production (HDP) merupakan salah satu ukuran produktivitas ayam petelur yang diperoleh dengan membagi jumlah telur dengan jumlah ayam saat itu (Amrullah 2003). Egg mass dihitung berdasarkan HDP dan bobot telur. Konversi pakan diperoleh dari jumlah pakan yang dikonsumsi dan bobot telur yang dihasilkan.

Pengukuran indeks telur ditentukan berdasarkan lebar telur dibagi panjang telur. Haugh Unit merupakan salah satu parameter kualitas interior telur yang dihitung berdasarkantinggialbumindanbobottelur(Keener etal. 2006). Perhitungan nilai Haugh Unit (HU) yaitu sebagai berikut :

$$
\text { Haugh Unit }=100 \log \left(\mathrm{H}+7,57-1.7 \mathrm{~W}^{0,37}\right)
$$

\section{Keterangan :}

$\mathrm{H} \quad$ : tinggi albumin $(\mathrm{mm})$
$\mathrm{W} \quad$ : bobot telur $(\mathrm{g})$

\section{Rancangan Percobaan}

Penelitian ini menggunakan Rancangan Acak Lengkap (RAL) dengan perlakuan suhu $18{ }^{\circ} \mathrm{C}$ dan suhu $30{ }^{\circ} \mathrm{C}$. Penelitian ini terdiri dari 2 bagian, percobaan pertama yaitu dengan menggunakan sistem litter dan percobaan kedua menggunakan sistem individual cage.

Rumus Rancangan Acak Lengkap (RAL) menurut Matjjik dan Sumertajaya (2006) yaitu :

$$
Y_{i j}=\mu+P_{i}+\varepsilon_{i j}
$$

Keterangan :

$\mathrm{Y}_{\mathrm{ij}}=$ pengamatan pada perlakuan ke-i dan ulangan ke-j

$\mu=$ rataan umum

$\mathrm{Pi}=$ pengaruh taraf perlakuan ke- $\mathrm{i}\left(\mathrm{i}=18^{\circ} \mathrm{C}\right.$ dan $\left.\mathrm{i}=30^{\circ} \mathrm{C}\right)$

$\varepsilon i j=$ pengaruh acak pada perlakuan ke-i dan ulangan ke-j

\section{Peubah yang Diamati}

Peubah yang diamati meliputi:

1. Performa produksi (konsumsi pakan, hen day 
production, bobot telur, egg mass, dan konversi pakan (FCR))

2. Kualitas interior (indeks telur, nilai haugh unit, bobot, dan tebal kerabang serta kedalaman kantung udara)

3. Kualitas eksterior (abnormalitas, bentuk telur, keutuhan, dan kebersihan kerabang)

\section{Analisis Data}

Data performa produksi, nilai Haugh Unit, bobot dan tebal kerabang serta indeks telur dianalisis menggunakan t-test. Model matematika yang digunakan sebagai berikut (Matjjik dan Sumertajaya 2006):

$$
\mathrm{t}=\frac{\left(\mathrm{X}_{1}-\mathrm{X}_{2}\right)-\left(\mu_{1}-\mu_{2}\right)}{\mathrm{S}_{\mathrm{d}} \sqrt{\left(1 / \mathrm{n}_{1}\right)-\left(1 / \mathrm{n}_{2}\right)}}
$$

Keterangan:

$\begin{array}{ll}\mathrm{X}_{1} & \text { : rata-rata pengukuran } \\ \mathrm{X}_{2} & \text { : rata-rata pengukuran } \\ \mathrm{S}_{\mathrm{d}} & \text { : standar deviasi } \\ \mathrm{n}_{1} & \text { : jumlah data } 1 \\ \mathrm{n}_{2} & \text { : jumlah data } 2\end{array}$

Data abnormalitas, bentuk telur, keutuhan, kebersihan kerabang, dan kedalaman kantung udara diolah secara deskriptif.

\section{HASIL DAN PEMBAHASAN}

\section{Performa Produksi dan Kualitas Telur pada Sistem Litter}

Perbedaan suhu dapat mempengaruhi performa produksi dan kualitas telur, baik kualitas interior maupun kualitas eksterior.

\section{Performa Produksi}

Data performa produksi disajikan pada Tabel 2 . Suhu lingkungan yang tinggi memberikan pengaruh negatif terhadap performa produksi telur baik pada ayam petelur maupunpadaayamkampung(GunawandanSihombing2004).

Rataan konsumsi pakan pada kandang litter, baik pada suhu $18^{\circ} \mathrm{C}$ maupun pada suhu $30^{\circ} \mathrm{C}$ menunjukkan hasil yang tidak berbeda. Hal tersebut dikarenakan sistem pemberian pakan yang sudah ditentukan, yaitu $120 \mathrm{~g}$ per ekor per hari. Apabila pakan yang diberikan lebih dari 120 g ekor ${ }^{-1}$ hari $^{-1}$ kemungkinan hasilnya akan berbeda, karena kemampuan konsumsi pakan setiap ekor ayam tidak sama dan konsumsi pakan ayam pada suhu $18^{\circ} \mathrm{C}$ akan lebih baik jika dibandingkan dengan ayam yang berada pada suhu $30^{\circ} \mathrm{C}$. Gunawan dan Sihombing (2004) menyatakan suhu kandang di bawah thermoneutral zone $\left(21^{\circ} \mathrm{C}-24^{\circ} \mathrm{C}\right)$ menyebabkan konsumsi pakan ayam meningkat, sedangkan suhu kandang di atas suhu nyaman akan menurunkan konsumsi pakan. Penurunan konsumsi pakan salah satunya disebabkan oleh meningkatnya konsumsi air minum yang digunakan untuk mempertahankan suhu tubuh terhadap suhu lingkungan yang semakin panas. Nurcholis et al. (2009) menyatakan konsumsi pakan ayam petelur yang sedang berproduksi
Tabel 2 Rataan parameter performa produksi pada sistem litter

\begin{tabular}{|c|c|c|}
\hline \multirow[t]{2}{*}{ Parameter } & \multicolumn{2}{|c|}{ Suhu } \\
\hline & $18^{\circ} \mathrm{C}$ & $30^{\circ} \mathrm{C}$ \\
\hline $\begin{array}{l}\text { Konsumsi pakan (g ekor }{ }^{-1} \\
\text { minggu }^{-1} \text { ) }\end{array}$ & $840,00 \pm 0$ & $840,00 \pm 0$ \\
\hline Hen day production (\%) & $89,20 \pm 10,50$ & $86,10 \pm 14,00$ \\
\hline Bobot telur (g butir ${ }^{-1}$ ) & $61,44 \pm 3,98$ & $63,38 \pm 3,14$ \\
\hline Egg mass (g minggu $\left.{ }^{-1}\right)$ & $6864,00 \pm 747,00$ & $6727,00 \pm 735,00$ \\
\hline Konversi pakan & $2,20 \pm 0,16$ & $2,21 \pm 0,15$ \\
\hline
\end{tabular}

berkisar antara 100 g-120 g ekor $^{-1}$ hari $^{-1}$. Penggunaan sistem kandang juga dapat mempengaruhi konsumsi pakan, karena kandang litter yang notabene lebih luas akan menyebabkan ayam membutuhkan energi lebih banyak untuk mobilisasi sehingga membutuhkan pakan yang lebih banyak pula.

Produksi telur dapat dinyatakan dengan ukuran hen day egg production (HDP) dan egg mass. HDP yang tinggi umumnya diiringi dengan pemberian pakan yang mencukupi kebutuhan hidup pokok dan produksi. Rataan persentase HDP pada kandang dengan suhu $18^{\circ} \mathrm{C}$ dan $30^{\circ} \mathrm{C}$ tidak berbeda secara statistik meskipun HDP pada suhu $18^{\circ} \mathrm{C}$ lebih tinggi.

Bobot telur pada sistem litter baik pada suhu $18^{\circ} \mathrm{C}$ dan suhu $30^{\circ} \mathrm{C}$ tidak berbeda secara statistik, meskipun bobot telur pada suhu $18^{\circ} \mathrm{C}$ lebih rendah dibandingkan dengan bobot telur pada suhu $30^{\circ} \mathrm{C}$. Bobot telur dalam hal ini dipengaruhi oleh beberapa hal, diantaranya konsumsi pakan, hen day production dan massa telur. Egg mass menunjukkan hasil yang tidak berbeda antara kedua suhu $\left(18^{\circ} \mathrm{C}\right.$ dan $\left.30^{\circ} \mathrm{C}\right)$. Hal tersebut dikarenakan bobot telur pada suhu $18^{\circ} \mathrm{C}$ lebih rendah dibandingkan dengan suhu $30^{\circ} \mathrm{C}$. Nilai egg mass yang diperoleh dari perkalian HDP dan bobot telur menunjukkan hasil tidak berbeda.

Rataan konversi pakan (FCR) pada kandang dengan suhu $18^{\circ} \mathrm{C}$ dan $30^{\circ} \mathrm{C}$ tidak berbeda. Menurut Lokapirnasari et al. (2011), semakin tinggi FCR maka akan semakin buruk, artinya penggunaan pakan tersebut kurang ekonomis. Konversi pakan ayam petelur berkisar antara 2,1-2,3. Faktor-faktor yang dapat mempengaruhi konversi pakan diantaranya bentuk fisik pakan, berat badan ayam, kandungan nutrisi dalam ransum, lingkungan pemeliharaan, stres, dan jenis kelamin. Perhitungan konversi pakan dimaksudkan untuk mengetahui kemampuan ayam dalam mengubah pakan yang dikonsumsi menjadi telur dan melihat respon ayam terhadap kualitas pakan yang diberikan (Lokapirnasari et al. 2011).

\section{Kualitas Interior Telur}

Kualitas interior berhubungan dengan karakteristik fungsional telur. Salah satu faktor yang dapat mempengaruhi kualitas interior yaitu pebedaan suhu selama pemeliharaan. Tabel 3 menyajikan rataan parameter kualitas interior telur.

Indeks telur merupakan parameter yang digunakan untuk menilai bentuk telur. Soeparno et al. (2011) menyatakan standar indeks bentuk telur sebesar 0,74 atau $74 \%$. Rataan indeks telur pada suhu $18^{\circ} \mathrm{C}$ dan suhu $30^{\circ} \mathrm{C}$ tidak berbeda, hal ini menunjukkan suhu selama pemeliharaan tidak mempengaruhi indeks telur. Menurut Soeparno et al. (2011), bentuk dan berat telur tergantung 
Tabel 3 Rataan parameter kualitas interior telur pada sistem litter

\begin{tabular}{lcc}
\hline Parameter & \multicolumn{2}{c}{ Suhu } \\
\cline { 2 - 3 } & $18^{\circ} \mathrm{C}$ & $30^{\circ} \mathrm{C}$ \\
\hline Indeks telur & $0,78 \pm 0,02$ & $0,78 \pm 0,02$ \\
Tebal kerabang (mm) & $0,42 \pm 0,04$ & $0,42 \pm 0,04$ \\
Bobot kerabang $(\mathrm{g})$ & $6,91 \pm 0,65$ & $7,59 \pm 0,80$ \\
Nilai HU & $74,20 \pm 13,40$ & $73,90 \pm 10,30$ \\
\hline
\end{tabular}

pada hereditas, umur induk, musim dalam setahun, dan pakan. Menurut penelitian yang telah dilakukan oleh Robert dan Ball (1998), panjang dan lebar telur sangat bervariasi dan tidak dipengaruhi secara signifikan oleh cekaman panas.

Suhu tinggi menyebabkan ayam melakukan panting sehingga terjadi penurunan konsentrasi $\mathrm{CO}_{2}$ di dalam darah. $\mathrm{CO}_{2}$ yang dikeluarkan pada saat panting bersamaan dengan air dan panas tubuh. Berkurangnya $\mathrm{CO}_{2}$ dalam darah mempengaruhi proses pembentukan kerabang. Terbentuknya kerabang karena adanya ion kalsium dan ion karbonat. Ion karbonat terbentuk karena adanya $\mathrm{CO}_{2}$ dalam darah sebagai hasil metabolisme sel yang terdapat pada uterus. Adanya $\mathrm{H}_{2} \mathrm{O}$ merombak kedua ion tersebut dibantu oleh enzim carbonic anhydrase yang dihasilkan oleh sel mukosa uterus menjadi ion bikarbonat dan selanjutnya menjadi ion karbonat setelah hidrogen lepas. Selain itu, proses metabolisme di dalam tubuh ayam pun berubah (Roberts dan Ball 1998). Rataan tebal kerabang pada suhu $18^{\circ} \mathrm{C}$ sama dengan suhu $30^{\circ} \mathrm{C}$. Suhu tinggi belum menunjukkan pengaruh nyata terhadap tebal kerabang.

Kerabang dengan permukaan berpori merupakan pembungkus telur yang paling tebal, bersifat keras dan kaku. Pori-pori yang terdapat pada kerabang berfungsi untuk pertukaran gas. Permukaan luar kerabang terdapat lapisan kutikula yang merupakan pembungkus telur paling luar. Berdasarkan t-test, bobot kerabang dari ayam pada sistem litter dengan suhu $18^{\circ} \mathrm{C}$ dan $30^{\circ} \mathrm{C}$ secara statistik tidak berbeda. Bobot kerabang berhubungan langsung dengan ketersediaan kalsium pada saat pembentukan kerabang telur. Ketersedian kalsium dapat dipengaruhi oleh panting, karena pada saat panting ayam mengeluarkan $\mathrm{CO}_{2}$, air dan panas. $\mathrm{CO}_{2}$ dan air turut berperan dalam pembentukan kalsium karbonat.

Haugh Unit merupakan salah satu parameter yang dapat digunakan untuk menentukan kulitas sebutir telur melalui kekentalan albumin dan bobot telur. Rataan nilai HU pada kandang dengan suhu $18^{\circ} \mathrm{C}$ dan suhu $30^{\circ} \mathrm{C}$ tidak berbeda secara statistik. Perbedaan suhu kandang belum mempengaruhi nilai Haugh Unit. Nilai HU baik pada suhu $18^{\circ} \mathrm{C}$ dan $30^{\circ} \mathrm{C}$ dikategorikan ke dalam kualitas AA yaitu $>72$ menurut USDA (1964). USDA mengelompokkan nilai Haugh Unit menjadi beberapa kategori yaitu AA untuk nilai HU >72, A untuk nilai HU 60-72, B untuk nilai HU 31-60 dan $\mathrm{C}$ untuk nilai $\mathrm{HU}<31$. Menurut Silverside dan Scott (2001), tinggi albumin dipengaruhi oleh jenis dan umur ayam saat bertelur, waktu penyimpanan dan kondisi selama penyimpanan. Telur yangsemakinlamadisimpan maka akan kehilangan karbondioksida dan uap air melalui pori-pori kerabang. Telur yang dianalisis pada penelitian ini merupakan telur segar yang belum mengalami proses penyimpanan, sehingga kekentalan albumin masih dalam keadaan baik. Kualitas Eksterior Telur

Rataan parameter kualitas eksternal telur pada penelitian ini disajikan pada Tabel 4. Abnormalitas telur meliputi bentuk telur yang tidak semestinya, kerabang lunak dan kerabang kasar akibat deposisi kalsium yang tidak merata (Barbosa et al. 2006). Persentase telur normal mencapai $100 \%$ dan tidak terdapat telur berbentuk abnormal, baik pada suhu netral $\left(18^{\circ} \mathrm{C}\right)$ maupun suhu tinggi $\left(30^{\circ} \mathrm{C}\right)$. Bentuk telur tidak dipengaruhi oleh suhu, tetapi dipengaruhi oleh genetik dan penyakit.

Bentuk telur terdiri dari beberapa kelompok, yaitu biconical (kedua ujungnya runcing), conical (salah satu ujungnya runcing), elliptical (menyerupai elips), oval yang merupakan bentuk telur paling baik, dan spherical (hampir bulat) (Gerber 2006). Bentuk telur secara umum dipengaruhi oleh faktor genetik. Suhu selama pemeliharaan tidak berpengaruh terhadap bentuk telur.

Keutuhan merupakan salah satu parameter untuk menilai kualitas sebutir telur. Telur yang sudah tidak utuh (kerabang retak) berkualitas buruk karena akan mudah terkontaminasi oleh bakteri dari luar dan dapat membahayakan konsumen. Persentase telur utuh mencapai $100 \%$, hal tersebut menunjukkan telur dalam keadaan baik dan kerabang tidak retak atau pecah. Keutuhan telur tidak dipengaruhi oleh suhu pemeliharaan. Keretakan pada kerabang dapat disebabkan oleh beberapa hal seperti terinjak oleh ayam dan terkena lantai kandang. Pengambilan telur pada penelitian ini dilakukan sesering mungkin untuk menjaga supaya telur tidak terinjak oleh ayam.

Kebersihan kerabang pada suhu $18^{\circ} \mathrm{C}$ dan $30^{\circ} \mathrm{C}$ bervariasi. Kebersihan kerabang lebih dipengaruhi oleh sistem pemeliharaan dan konsumsi air minum. Ayam pada suhu tinggi akan mengkonsumsi air minum lebih banyak sehingga kotoran yang dihasilkan akan semakin banyak dan encer. Hal tersebut dapat mengakibatkan telur menjadi lebih kotor.

Tabel 4 Persentase parameter kualitas eksterior telur pada sistem litter

\begin{tabular}{lcc}
\hline \multicolumn{1}{c}{ Parameter } & Suhu & \\
\cline { 2 - 3 } & $18^{\circ} \mathrm{C}$ & $30^{\circ} \mathrm{C}$ \\
\hline Abnormalitas (\%) & 0 & 0 \\
Bentuk telur (\%) & & \\
Lonjong & 16,67 & 16,67 \\
Agak bulat & 27,78 & 33,33 \\
$\quad$ Oval & 55,56 & 50 \\
Keutuhan kerabang (\%) & 100 & 100 \\
Tingkat kekotoran kerabang (\%) & & \\
1/8 & 0 & 16,67 \\
1/16 & 50 & 16,67 \\
1/32 & 50 & 66,67 \\
Kedalaman kantung udara (\%) & & \\
AA & 94,44 & 94,44 \\
A & 5,56 & 5,56 \\
\hline
\end{tabular}


Tidak adanya kantung udara disebabkan oleh temperatur yang sama antara suhu induk dengan suhu lingkungan pada saat telur dikeluarkan yaitu sekitar 40-42 ${ }^{\circ}$ C. Kantung udara mulai terbentuk ketika telur disimpan pada suhu ruang. Pori-pori pada kerabang telur memungkinkan udara masuk dan menyebabkan putih telur menguap, yang menyebabkan kantung udara menjadi lebih besar. Kedalaman kantung udara dilihat melalui peneropongan atau candling. Mutu atau kualitas telur dipengaruhi oleh adanya kantung telur yang terdapat pada bagian tumpul ujung telur (Al-Helal 2013). Kedalaman kantung udara telur penelitian termasuk dalam kategori AA dan A. Hal tersebut menunjukkan kantung udara masih dalam keadaan kecil dan baik. Semakin lama penyimpanan semakin besar ukuran kantung udara, karena penguapan air akan menyebabkan penempelan membran luar pada kerabang, dan membran dalam menempel pada albumin. Telur pada penelitian ini dianalisis dalam keadaan segar dan tidak disimpan dalam waktu lama, sehingga suhu kandang tidak menimbulkan dampak buruk terhadap kantung udara.

\section{Performa Produksi dan Kualitas Telur pada Sistem Cage}

Performa produksi dan kualitas telur salah satunya dipengaruhi oleh suhu. Suhu yang tinggi dapat memberikan pengaruh yang buruk terhadap ayam, sehingga berakibat pada produksi dan kualitas telur.

\section{Performa Produksi}

Penelitian ini mengamati performa produksi pada kandang cage yang meliputi konsumsi pakan, hen day production, bobot telur, dan konversi pakan. Rataan parameter dapat dilihat pada Tabel 5.

Beberapa peneliti melaporkan bahwa suhu lingkungan mempengaruhi konsumsi pakan. Tabel 5 menyajikan rataan konsumsi pakan pada kandang cage suhu $18^{\circ} \mathrm{C}$ dan $30^{\circ} \mathrm{C}$. Data menunjukkan hasil yang berbeda nyata. Konsumsi pakan pada suhu lingkungan rendah lebih tinggi jika dibandingkan dengan konsumsi pakan pada suhu lingkungan yang tinggi.

Produksi telur harian (hen day egg production) merupakan salah satu ukuran produktivitas ayam petelur yang diperoleh dengan membagi jumlah telur dengan jumlah ayam saat itu (Amrullah 2003). HDP pada suhu $18^{\circ} \mathrm{C}$ dan $30^{\circ} \mathrm{C}$ tidak berbeda secara statistik.

Bobot telur pada suhu $18^{\circ} \mathrm{C}$ dan suhu $30^{\circ} \mathrm{C}$ menunjukkan hasil yang berbeda secara statisik. Bobot telur pada suhu $18^{\circ} \mathrm{C}$ lebih tinggi dibandingkan dengan

Tabel 5 Rataan parameter performa produksi pada sistem cage

\begin{tabular}{|c|c|c|}
\hline \multirow[t]{2}{*}{ Parameter } & \multicolumn{2}{|c|}{ Suhu } \\
\hline & $18^{\circ} \mathrm{C}$ & $30^{\circ} \mathrm{C}$ \\
\hline $\begin{array}{l}\text { Konsumsi pakan } \quad \text { (g ekor }{ }^{-1} \\
\operatorname{minggu}^{-1} \text { ) }\end{array}$ & $830,80 \pm 8,80 \mathrm{a}$ & $818,01 \pm 8,46 b$ \\
\hline Hen day production (\%) & $89,30 \pm 1,50 \mathrm{a}$ & $87,70 \pm 12,90 \mathrm{a}$ \\
\hline Bobot telur (g butir ${ }^{-1}$ ) & $62,19 \pm 3,27 \mathrm{a}$ & $60,44 \pm 3,19 b$ \\
\hline Egg mass $\left(g\right.$ minggu $\left.^{-1}\right)$ & $6.987,00 \pm 721,00 \mathrm{a}$ & $6.661,00 \pm 870,00 \mathrm{a}$ \\
\hline Konversi pakan & $2,14 \pm 0,22 \mathrm{a}$ & $2,25 \pm 0,46 \mathrm{a}$ \\
\hline
\end{tabular}

Keterangan : Huruf yang berbeda pada angka-angka di baris yang sama menunjukkan perbedaan yang nyata $(\mathrm{P}<0.05)$ suhu $30^{\circ} \mathrm{C}$. Bobot telur dan produksi telur berkorelasi negatif terhadap suhu. Penurunan produksi telur dan bobot telur yang terjadi disebabkan oleh suhu tinggi. Suhu diatas $27^{\circ} \mathrm{C}$ memberikan pengaruh negatif terhadap konsumsi pakan dan bobot telur (Talukder 2010). Suhu lingkungan yang tinggi membutuhkan energi yang lebih banyak untuk pengaturan suhu tubuh, sehingga mengurangi penyediaan energi untuk produksi telur (Latipudin dan Mushawwir 2011).

Turunnya konsumsi pakan menyebabkan berkurangnya nutrisi dalam tubuh danakhirnyamenurunkan produksi telur (Siahaan et al. 2013). Egg mass pada suhu $18^{\circ} \mathrm{C}$ dan suhu $30^{\circ} \mathrm{C}$ menunjukkan hasil yang tidak berbeda nyata secara statistik, meskipun pada suhu $18^{\circ} \mathrm{C}$ nilai egg mass lebih tinggi. Nilai egg mass tergantung dari persentase produksi telur harian dan berat telur. Apabila egg mass meningkat maka produksi telur meningkat, sebaliknya egg mass turun produksi telur menurun (Amrullah 2003).

Semakin tinggi suhu lingkungan maka ayam akan mengurangi konsumsi pakan dan meningkatkan konsumsi minum untuk mengurangi panas tubuh. FCR pada suhu $18^{\circ} \mathrm{C}$ dan $30^{\circ} \mathrm{C}$ secara statistik tidak berbeda. Secara umum, FCR merupakan jumlah pakan yang diberikanuntukmenghasilkan produk dalam jumlah tertentu (Lokapirnasari et al. 2011).

\section{Kualitas Interior Telur}

Kualitas interior telur yang diamati dalam penelitian ini meliputi indeks telur, tebal, dan bobot kerabang serta nilai Haugh Unit. Rataan parameter kualitas interior telur dapat dilihat pada Tabel 6 .

Indeks telur tidak dipengaruhi oleh suhu atau sistem perkandangan. Menurut Soeparno et al. (2011), bentuk dan berat telur tergantung padahereditas, umur induk, musim, dan pakan. Indeks telur pada suhu kandang $18^{\circ} \mathrm{C}$ tidak berbeda secara statistik dengan suhu $30^{\circ} \mathrm{C}$. Semakin besar nilai indeks telur menunjukkan bentuk telur yang semakin bulat.

Kerabang telur sebagian besar disusun oleh kalsium. Rataan tebal kerabang pada suhu $18^{\circ} \mathrm{C}$ dan $30^{\circ} \mathrm{C}$ tidak berbeda secara statistik meskipun rataan tebal kerabang pada suhu $18^{\circ} \mathrm{C}$ lebih tinggi. Sesuai dengan yang dinyatakan oleh Grieve (2004) bahwa pada lingkungan yang panas, ayam bereaksi dengan meningkatkan laju pernapasan (panting) untuk mengeluarkan panas tubuh. Hal ini menyebabkan penurunan $\mathrm{CO}_{2}$ dalam darah dan $\mathrm{pH}$ darah menjadi basa. Barbosa et al. (2006) menyatakan, semakin tinggi $\mathrm{pH}$ darah maka jumlah kalsium dalam darah yang digunakan untuk pembentukan kerabang semakin berkurang, akibatnya kerabang menjadi lebih tipis.

Tebal kerabang dan bobot kerabang memiliki korelasi positif. Semakin tebal kerabang, maka akan semakin berat bobotnya. Rataan bobot kerabang pada suhu

Tabel 6 Rataan parameter kualitas interior telur pada sistem cage

\begin{tabular}{lcc}
\hline \multirow{1}{*}{ Parameter } & \multicolumn{2}{c}{ Suhu } \\
\cline { 2 - 3 } & $0,79 \pm 0,03$ & $0,78 \pm 0,03$ \\
\hline Indeks telur & $0,43 \pm 0,06$ & $0,40 \pm 0,05$ \\
Tebal kerabang $(\mathrm{mm})$ & $7,45 \pm 0,52$ & $7,22 \pm 0,77$ \\
Bobot kerabang $(\mathrm{g})$ & $79,20 \pm 12,60$ & $76,70 \pm 15,70$ \\
Nilai HU &
\end{tabular}


$18^{\circ} \mathrm{C}$ dan suhu $30^{\circ} \mathrm{C}$ tidak berbeda. Laju metabolisme dan konsumsi pakan ayam pada suhu netral akan berjalan normal. Kebutuhan kalsium akan terpenuhi oleh pakan, sehingga kerabang telur yang dihasilkan tidak tipis. Tebal tipisnya kerabang telur dipengaruhi oleh strain ayam, umur induk, pakan, stres, dan penyakit pada induk. Semakin tua umur ayam maka semakin tipis kerabang telur yang dihasilkan, hal ini dikarenakan ayam tidak mampu memproduksi kalsium yang cukup guna memenuhi kebutuhan kalsium dalam pembentukan kerabang (Grieve 2004). Nilai Haugh Unit pada kandang cage dengan suhu $18^{\circ} \mathrm{C}$ lebih tinggi dibandingkan dengan suhu $30^{\circ} \mathrm{C}$ meskipun secara statistik tidak berbeda. Keduanya masih termasuk dalam kategori AA menurut USDA (1964), karena nilai HU $>72$. Kualitas Eksterior Telur

Kualitas eksterior telur meliputi abnormalitas, bentuktelur, keutuhan kerabang, dan kebersihan kerabang. Rataan parameter kualitas eksterior telur disajikan pada Tabel 7.

Persentase telur normal mencapai 100\%, yang berarti tidak terdapat telur yang abnormal, baik pada suhu $18^{\circ} \mathrm{C}$ maupun suhu $30^{\circ} \mathrm{C}$. Bentuk telur dipengaruhi oleh genetik dan penyakit dan tidak dipengaruhi oleh suhu dan sistem pemeliharaan. Persentase keutuhan telur mencapai $100 \%$, artinya seluruh telur tidak mengalami keretakan kerabang. Kebersihan kerabang bervariasi dan tidak dipengaruhi oleh suhu selama pemeliharaan, tetapi dipengaruhi oleh sistem pemeliharaan. Telur pada kandang cage lebih bersih karena telur ayam tidak jatuh ke bedding, melainkan ke tempat telur di bagian depan kandang cage. Telur pada penelitian ini termasuk dalam kategori AA, karena pengukuran kantung udara dilakukan pada saat telur masih segar dan belum tersimpan lama dalam ruang. Kantung udara mulai terbentuk ketika telur disimpan pada suhu ruang (Garry et al. 2009).

\section{Diskusi Umum}

Berdasarkan hipotesis awal, ayam petelur yang

Tabel 7 Persentase parameter kualitas eksterior telur pada sistem cage

\begin{tabular}{lcc}
\hline \multirow{2}{*}{ Parameter } & \multicolumn{2}{c}{ Suhu } \\
\cline { 2 - 3 } & $18^{\circ} \mathrm{C}$ & $30^{\circ} \mathrm{C}$ \\
\hline Abnormalitas (\%) & 0 & 0 \\
Bentuk telur (\%) & & \\
Lonjong & 33,33 & 33,33 \\
Agak bulat & 44,44 & 11,11 \\
Oval & 22,22 & 55,56 \\
Keutuhan kerabang (\%) & 100 & 100 \\
Tingkat kekotoran kerabang (\%) & & \\
$1 / 8$ & 0 & 0 \\
$1 / 16$ & 33,33 & 50 \\
$1 / 32$ & 66,67 & 50 \\
Kedalaman kantung udara (\%) & & \\
AA & 100 & 100 \\
A & 0 & 0 \\
\hline
\end{tabular}

dipelihara pada suhu lingkungan $30^{\circ} \mathrm{C}$ memiliki performa produksi dan kualitas telur yang lebih rendah. Hal tersebut tidak sejalan dengan hasil penelitian ini. Hasil penelitian menunjukkan performa produksi dan kualitas telur hampir sama antara suhu $18^{\circ} \mathrm{C}$ dan $30^{\circ} \mathrm{C}$, baik pada sistem kandang litter maupun cage.

Masing-masing sistem kandang yaitu litter dan cage memiliki kekurangan dan kelebihan. Ditinjau dari segi kesejahteraan ternak, ayam pada sistem litter akan lebih sejahtera karena ruang gerak ayam yang lebih luas. Namun kekurangan sistem ini yaitu telur yang langsung terletak pada alas (bedding) akan lebih mudah terkontaminasi oleh bakteri, mengingat ayam pada kandang litter akan membuang kotorannya di sekitar alas. Tetapi hal ini dapat diatasi dengan penambahan sarang untuk ayam bertelur, sehingga kemanan dan kebersihan telur dapat terjaga. Kandang cage merupakan kandang yang populer digunakan peternak ayam petelur di Indonesia, tetapi pada peternakan pembibitan (breeder) ayam pada kandang cage tidak dapat bebas bergerak karena keterbatasan ruang dan hal ini bertentangan dengan kesejahteraan ternak. Performa produksi ayam pada sistem cage lebih baik karena penggunaan pakan difokuskan untuk menghasilkan telur.

\section{KESIMPULAN}

Ayam petelur memiliki performa produksi lebih baik dan kualitas interior telur yang tinggi pada kandang cage dengan suhu netral $\left(18^{\circ} \mathrm{C}\right)$. Abnormalitas, bentuk telur, keutuhan kerabang, dan kebersihan kerabang tidak dipengaruhi oleh suhu tetapi lebih dipengaruhi oleh genetik dan sistem perkandangan.

\section{DAFTAR PUSTAKA}

Akyurek H, Okur AA. 2009. Effect of storage time, temperature and hen age on egg quality in freerange layer hens. Journal of Animal and Veterinary Advances. 8: 1953-1958.

Al-Helal IM. 2003. Environmental control for poultry building in Riyadh Area of Saudi Arabia. J. King Saud. Univ. 16(1): 87-102.

Amrullah IK. 2003. Nutrisi Ayam Petelur. Bogor (ID): Satu Gunungbudi.

Hall A. 2000. Egg Formation and Eggshell Quality in Layers. Canada (CN): Nutreco Canada Inc.

Barbosa JAD, Silva MAN, Silva IJO, Coelho AAD. 2006. Egg quality in layers housed in different production systems and submitted to two environmental conditions. Brzil (BR): Departamento de Engenharia Rural. 2: 150204.

Gerber N. 2006. Factors affecting egg quality in commercial laying hen: a review. Auckland (NZ): Poultry Industri Association of New Zeland.

Grieve D. 2004. Environmental stress and amelioration in livestock production. Australian Jurnal Expo Agricultural. 34: 285-295.

Gunawan, Sihombing DTH. 2004. Pengaruh suhu lingkungan tinggi terhadap kondisi fisiologis dan 
produktivitas ayam buras. Wartazoa. 14(1): 31-38.

Indratiningsih. 2006. Dasar Teknologi Hasil Ternak. Yogyakarta (ID): Gadjah Mada University Pr.

Jacob JP, Miles RD, Mather FB. 2000. Egg Quality 1. United States of America (US): University of Florida.

Keener KM, McAvoy Foegeding JB, Curtis PA, Anderson KE, Osborne JA. 2006. Effect of testing temperature on internal egg quality measurement. Poultry Science Association. 85:550-555.

Latipudin D, Mushawwir A. 2011. Regulasi panas tubuh ayam ras petelur fase grower dan layer. Jurnal Sains Peternakan Indonesia. 6(2): 77-82.

Lokapirnasari WP, Soewarno, Dhamayanti Y. 2011. Potensi crude spirulina terhadap protein efisiensi rasio pada ayam petelur. Jurnal Ilmiah Kedokteran Hewan. 2: 5-8.

Matjjik AA, Sumertayaja II. 2006. Perancangan Percobaan dengan Aplikasi SAS dan Minitab jilid I. Bogor (ID): IPB Pr.

North MO, Bell D. 1990. Commercial chicken production manual. United States of America (US): Incorporate.

Nurcholis, Hastuti D, Sutiono B. 2009. Tatalaksana pemeliharaan ayam ras petelur periode layer di Populer Farm Desa Kuncen Kecamatan Mijen Kota Semarang. Jurnal Ilmu-ilmu Pertanian. 5(2): 38-49.

Robert JR, Ball W. 1998. Effect of heat stress on egg and egg shell quality in five strains of laying hen. Proc. Aust. Poul. Sci. Sym.

Siahaan NB, Suprijatna E, Mahfudz LE. 2013. Pengaruh penambahan tepung jahe merah (Zingiber officinale var. Rubrum) Dalam ransum terhadap laju bobot badan dan produksi telur ayam kampung periode layer. Animal Agricultural Journal. 2(1): 478-488

Silverside D, Scott GB. 2001. House, husbandry and welfare of poultry. United State of America (US): National Agricultural Library.

Soeparno, R.A. Rihastuti, Indratiningsih, Suharjono Triatmojo. 2011. Dasar Teknologi Hasil Ternak. Yogyakarta (ID): Gadjah Mada University Pr. Talukder S, T Islam, S Sarker and MM Islam. 2010. Effects of environment on layer performance. J. Bangladesh Agril. Univ. 8(2): 253-258

[USDA] United States Department of Agriculture. 1964. Egg Grading Manual. Washington DC (US): Federal Crop Insurance Corporation (FCIC). 